\title{
Bowing to a Higher Authority
}

In several of Hochwälder's plays characters, often with the best intentions, choose to subjugate their own feelings and ignore the voice of their consciences in the belief that they are better to serve a higher authority, be this from religious, political or philosophical conviction. Inevitably, such behaviour has unforeseen and often disastrous results. Furthermore, it may be used as justification for injustice and persecution.

Several of Hochwälder's plays explore this issue. The underlying theme of plays such as Donadieu and Die Herberge, is that individuals must ultimately look to themselves rather than a higher authority if they wish good to be done, while characters in plays such as Esther and Die Bürgschaft make the error of believing positive change can be brought about by working within fundamentally corrupt governments, or, as has already been seen in Der öffentliche Ankläger, battle such regimes under political ideologies that justify immoral means with virtuous ends.

The clearest demonstration of the dangers of placing one's faith in the authority one serves appears in Das heilige Experiment. In this powerful drama both the servants of church and state, who find themselves victims of a political conflict they have little control over, sacrifice personal convictions to obedience, only to learn too late they have made a terrible mistake.

It has already been seen that in Donadieu the central characters of Isaac von Donadieu and his counterpart Lavalette demonstrate the merits of acting according to their consciences. The play set in a time of religious conflict, when both sides claim to represent the true word of God, demonstrates the dangers of ideologically motivated actions. Significantly both Catholic and Protestant forces produce their war criminals, Du Bosc and Tiefenbach.

That the same religious basis can be used to justify quite contrary courses of action is also shown by the protagonist's efforts to justify his desire for revenge in biblical terms (II, 12, 13, 27, 37, 39-40), which is countered, using the same religious source, by both Berthelien and Judith (II, 12, 13, 26, 52). Despite the nobility with which the central character sacrifices his personal desires for the general good at the end, his religious belief is shown in a far from uncritical light. Nowhere does it come under sharper attack than from Lavalette in Act II, who berates the inhumanity of the Calvinist doctrine of predestination, which condemns those not chosen to eternal damnation from birth, who damns Protestant behaviour which he sees as treasonous and the cause of numerous civil wars in Europe, and who paints Calvinist Geneva as a puritanical police state (II, 48-49) ${ }^{1}$.

But the most important critique of both ideologies at the centre of the war comes from the Hanswurst figure of Escambarlat, who has suffered intoleran-

1 It is worth noting that in criticising Marxism, in his essay "Über mein Theater", Hochwälder likens it to the Calvinist doctrine of predestination [Im Wechsel der Zeit, 120, 129]. 
ce at the hands of both Catholics and Protestants. In the humorous opening scene the poet rigorously defends himself against Barbe's accusation of being a good-for-nothing, complaining he is always misunderstood:

ESCAMBARLAT: Ich beschäftige mich unaufhörlich. Ich dichte.

BARBE: Ihr treibt Unzucht mit Worten.

ESCAMBARLAT: Das hat man mir schon in Genf vorgeworfen, nebst andern Kleinigkeiten. Was kann ich dafür, wenn das Konsistorium keinen Humor hat? - Und in Paris haben mich die andern verfolgt, weil ich Gottes reines Wort in Verse gebracht hab... Ich möchte wissen, wie man es allen recht machen soll?

BARBE: Man lebt gottgefällig, das genügt.

ESCAMBARLAT: Ich lebe durchaus gottgefällig, aber es hat sich erwiesen, daß das nicht genügt, heutzutage.

(II, 10)

But comical though this scene may be, there is undoubtedly a serious edge to Escambarlat's dream of freedom: "Gäbe es in diesem unglückseligen Land einen Ort, wo der Geist nicht verfolgt und unterdrückt wird, hüben wie drüben - glaubst du, ich würd nicht mit Freuden davonlaufen, heut noch, trotz Sturm und Regen?" (II, 10).

He reveals more of this serious side in candid conversation with Lavalette in Act II, when he describes how he came to his Protestant convictions, spurred on by the injustices he saw in the Paris of his youth. His libellous writings against the crown forced him to flee to Geneva: "Mir blieb nichts anderes als die Flucht ins Paradies" (II, 30), but here too his behaviour soon saw him fall from grace. Nevertheless, he cannot quite shake off his dream of utopian justice, even if he hopes it will never come to pass (II, 30).

The sentiments expressed by Escambarlat here are at the heart of Hochwälder's treatise on liberty, "Kann die Freiheit überleben?"2. To dream of a just world is one thing, to put it into practice is another, and any attempt to do so inevitably creates more injustice, as it implies imposing a set of values and behaviour on individuals.

It is in this light that Lavalette's dictum: "Recht tun heißt: sich reinigen vom eignen Bösen" (II, 62) should be seen. Ideals are not rejected per se, but the only real way to work towards a better world is to start with one's own behaviour and to look within oneself.

In Die Herberge, voice is given to similar sentiments by the mystical wanderer, Schimke. He arrives in the third act and not only contributes to justice being done, but also challenges the basis on which the magistrate, Smalejus, has carried out his duties.

Smalejus, in his office of magistrate, is required to administer the system of justice which exists in a patently unjust world. However, it quickly becomes clear that he himself, influenced by a nihilistic philosophy (II, 102), does not believe in justice, on earth or in heaven:

${ }^{2}$ Cf. Hochwälder, Im Wechsel der Zeit, 129 [See Chapter 7]. 
SMALEJUS: Gäbe es einen Wirt, der alle Schuld aufschreibt und einfordert zur Zeit, dann könnte es geschehn, daß der Dieb gefragt wird: "Wer hat dich bestohlen?" und der Mörder: "Was hat man dir getan?". Dann könnte es geschehn, daß eines Tags ein Ruf erschallt: "Jedem das Seine!" - Doch so ein Wirt ist nicht, nicht im Himmel, nicht auf Erden, nirgends. [...] Da es keine Gerechtigkeit gibt, muß Ordnung herrschen. Besser, zehn Unschuldige sterben, als daß ein Schuldiger ungestraft davonkommt $[\ldots]$

BERULLIS verwirrt: ... Ordnung... was nennst du Ordnung?

SMALEJUS: Unrecht.

He quite consciously carries out actions he knows to be wrong, but, in a terrible world, believes them to be in the general interest. Yet it is a task which takes its toll:

Schmerzen plagen mich, Nacht für Nacht. In den Beinen sticht es, pocht, hämmert, läßt nicht schlafen. Wer nicht schläft, liest. Wer liest, denkt. Wer denkt, schätzt die Welt ein, wie sie ist. Wer die Welt einschätzt, wie sie ist, weiß: bloß Ordnung hält sie in ihrer Bahn. Nichts außer Ordnung schützt den Menschen vor den Menschen!

(II, 101)

In many respects he has much in common with Dostoevsky's Grand Inquisitor ${ }^{3}$. He recognizes the weakness of his fellow man, and takes on the burden of guilt, indicated by his frail health, to make life partly bearable by instigating order on the callous world around him.

His position is undermined in the third act, both by the course of events and by the arrival of Schimke, whose appearance suggests the workings of a higher power: "Ich wandere... zieh von Ort zu Ort... Überall wo man mich braucht, muß ich sein..." (II, 123). Furthermore Schimke describes how, having already left the village, he felt compelled to return, as if by some greater force: “... mit einem Mal hab ich gespürt: ich darf nicht weiter... muß zurück..." (II, 126).

While the other characters remain in awe and fearful of Smalejus, Schimke rather pities him, recognizing the weight of responsibility which rests with his interrogator:

Was hast du dir für eine schwere Bürde aufgeladen, Herr! Über Menschen richten [...] das Unrecht aufspüren, wo es begraben ist: tief in der Brust... was ist das für ein schreckliches Amt! [...] Wahrhaftig - ich möcht nicht mit dir tauschen...

(II, 123)

3 Fyodor Dostoevsky, "The Grand Inquisitor", The Brothers Karamazov. A Novel in Four Parts with Epilogue, Trans. Richard Pevear and Larissa Volokhonsky, (London: Vintage, 1990), 246-264. Hochwälder goes so far as to provide a short synopsis of the story Ivan tells his brother Alyosha, which serves to illustrate his thoughts on freedom [Im Wechsel der Zeit, 125-128]. This essay, and Dostoevsky's influence, will be examined in more detail in Chapter 7. 
The wanderer's presence proves to be the catalyst for the truth to be revealed, since Jurgis cannot stand by and watch an innocent man being punished for something he has done (II, 127), and as a result, both Jurgis and Berullis, at least for a while, feel the stirring of their consciences (II, 132-133).

As events unfold, justice, unlikely though it seems in such a world, is seen to be done. The question remains as to how it came to pass, and Smalejus gives voice, albeit with uncertainty, to the notion that it has all been a matter of chance:

Der Blinde, der im Irrtum Wahrheit findet - einmal, ein einziges Mal! handelt der gerecht? Was zwischen Traum und Wachen verweht, geschieht das immer? Was einmal war, ist nicht gewesen! Die Welt läuft immerzu und immerzu wird dieses sein: Der Fuhrmann flieht, kehrt in den Wald zurück, bis ihn ein neues Opfer lockt; der Makler rächt sich am nächsten Schuldner; der Holzfäller bleibt arm wie zuvor - was für ein Wirt ist das, was für eine Herberge, was für ein Ort, niedrig, schmutzig, gemein!

In part, Schimke would seem to agree with the cynical Amtmann, as his remarks on Berullis show: "... da erkennt der Mensch, daß alles ist wie Ruf und Widerhall - und er geht hin und vergißt, als wär nichts gewesen..." (II, 137). But chance or not, an example of justice has been set, and to Smalejus' question: "Wo ist Gerechtigkeit?", the pilgrim can answer with the significant words: "In unserer Brust, Herr. Mitten im Unrecht wohnt Gottes Gerechtigkeit - wie ein Kern in der Frucht" (II, 137) ${ }^{4}$. Smalejus' view of the world remains sadly accurate, but Schimke provides the vision to improve $\mathrm{it}^{5}$, and, as with Lavalette's words at the end of Donadieu, the emphasis is firmly placed upon the individual.

The final moment of the play takes on great symbolism through the contrast between these two views: the cynicism of the old man, as opposed to the simple but profound faith of the vagrant. A weak Smalejus must ask for help from Schimke and rely on his support as the play closes:

SMALEJUS: Hilf...

Schimke greift dem Amtmann unter die Arme, richtet ihn auf, reicht ihm Stock und Hut, hängt ihm den Mantel um, geleitet ihn zum Gang, bückt sich, um Bündel und Wanderstab aufzunehmen.

SMALEJUS angstvoll: Laß mich nicht los!

Schimke hält ihn.[...]

SMALEJUS: ... Hab Dank, Strannik... Hab Dank!

\footnotetext{
4 The last sentence of this quotation is inscribed on Hochwälder's gravestone in Vienna.

5 In a letter to James J. Schmitt, dated 12 April 1972, Hochwälder wrote: "In der Herberge vertrete ich natürlich die Ansicht des Wanderers Schimke, aber zum Teil auch die des Amtmanns, der auf das sekundenartige Aufleuchten der Gerechtigkeit in der Nacht unserer Welt hinweist" [James [J.] Schmitt, "Fritz Hochwälder's Dramas: 1943-1965", 63].
} 
Smalejus is not the only character created by Hochwälder to put too much faith in order and authority as the means of providing some security in an unjust world. Throughout Esther, Mordechai places far too much trust in the crown as the upholder of the law and the protector of the weak. His position is somewhat hypocritical, for while he expects the law to uphold his rights, he often shows little sympathy for others, most notably the masses as represented by his radical nephew Benjamin. Furthermore, while espousing the letter of the law, he is still cautious enough to try to arrange a future for Esther in which her Jewish origins will be disguised.

This misguided faith is apparent from the very first scene in which Mordechai appears. He strongly rejects the anti-Semitic threats of Dalphon by calling on the virtues of a free country "wo auch der Jud sein Recht bekommt durch Seiner Majestät allerhöchstes Gesetz" (I, 13). The audience, however, is already well aware, from the opening conversation between the king and Tharsis and Meres, of the troubled state of the nation (I, 10-11), and Meres later tries to spell out this precarious situation to Mordechai as he takes up his new job at the palace (I, 27). This warning has little impact on Mordechai, who takes his position very seriously: he tells Bigtan and Teresch that he will be strict and fair in ensuring they carry out their duties (I, 28); makes them work longer hours when they fail in this $(I, 31)$; expresses a desire to improve the sorry state of affairs he finds at the palace (I, 31); and is proud of instituting measures to prevent spitting by all but the king in the palace ( $\mathrm{I}$, 50). Nowhere does Mordechai make this belief in the authority of the crown clearer than in rejecting Bigtan and Teresch's plea for mercy after he has uncovered their plot against the king:

Hättet ihr ausgeheckt ein Verbrechen wider mich oder wenn es gewesen wäre ein Anschlag gegen mein Leben, Beraubung meines Guts - ich hätt euch nicht an den Galgen geliefert und hätt es vergessen und verziehen. Aber habt ihr nicht, ihr Hunde, angetastet das Leben der Königlichen Majestät? - Da kann es geben keinen Pardon - denn wo käm die Welt hin und was würd aus allem Gesetz und jeglichem Recht, wenn der Ordnung Haupt fiel und der Pöbel fing an zu herrschen! - Drum keine Gnade für euch und euresgleichen - und wenn ich selbst sollt werden garottiert!

Mordechai, like Smalejus, has little concern with social justice, seeing order as of paramount importance, and like his bitter enemy Haman, has nothing but scorn for the masses ${ }^{7}$.

${ }^{6}$ It is surprising, given that Smalejus, the representative of order above justice, is portrayed as so weak at the end, that Donald Daviau has seen the play as a philosophical turning point for Hochwälder: "whereas he had argued for justice and for punishing war criminals, he now expresses his new idea that harmony and order are greater values to society than justice. In his mature view it is preferable to forget the past for the sake of restoring harmony in the present" [Daviau, Fritz Hochwälder", 251. Cf. Daviau, "Fritz Hochwälder's Range of Theme and Form", 37]. Daviau's attempt to explain the justice achieved at the end as a divine and rare phenomenon ["Fritz Hochwälder", 252] adds little weight to his argument.

7 It is worth noting here that at the time of writing Esther, Hochwälder considered himself a 
However, his faith in the crown's ability to keep order is decidedly naive. Despite what he sees around him, and the clear indications of growing antiSemitism, the rise of Haman seems ridiculous to him, as his conversation with Meres indicates:

MORDECHAI: Mich wundert nur eines: Daß Sie, ein vernünftiger Mensch, auch nur einen Augenblick glauben können solche Narrischkaten!

MERES: Und mich wundert, daß Sie, ein sonst so real denkender Mensch, sich in dieser Sache selbst betrügen. Sie sehen doch, wie das Volk seinen antisemitischen Parolen nachläuft!

MORDECHAI: Der Herr [Haman] wird noch hören von mir, wenn er nicht sehr bald sein wird still und bescheiden, wie es ihm zukommt. Aber vorläufig bin ich mir noch zu gut, hinzutreten vor einen Pöbelhaufen und zu rechten mit dieser armseligen Kreatur von einem Hetzer!

Such is his pride, and arrogant assumption that someone like Haman cannot be a threat, that, unlike Meier Helmbrecht, he does not succumb to the pressure of the others and bow before the conquering villain (I, 51).

Nevertheless, Mordechai must inevitably wake up to reality, and realize just how vulnerable he and his people are. It is Benjamin, whose politics the conservative Mordechai scorns (I, 58-59), who must explicitly explain the position of the Jews:

[...] Wir sind die Wehrlosen, deshalb waren und sind wir immer die Opfer. [...] Alles, was jüdisch geboren ist, wird zur höhern Ehre deines Staates hingemordet und ausgeplündert! Was wir uns auch immer für Verdienste erworben haben und was wir auch gewesen sein mögen: Schuldig oder unschuldig, reich oder arm, gut oder schlecht... jetzt sieh zu, wie du mit deinem Staat auskommst - du Staatsdiener!

Mordechai pins his hopes on Esther's position at the court, overlooking Benjamin's reproach that he could have given her to the king ( $I, 60)$, only to have them shattered when she writes to tell him that she can do nothing. Significantly it is now Benjamin, the long-time opponent of the regime, who must encourage Mordechai, so long its supporter, not to give up and to fight against it (I, 61).

But although Mordechai's eyes have been opened to the danger, he still cannot completely shake off the idea that justice, which like Donadieu he sees as synonymous with revenge, can be his, through the state. It is because of this attitude that he can claim victory over the fallen Haman, who only laughs back at him: "Du wirst bald sehen, Jude - daß nicht du es bist, der gesiegt hat" (I,

Marxist [Im Wechsel der Zeit, 28], which explains the introduction and sympathetic portrayal of the character, Benjamin, who serves little purpose in regard to the plot but does allow Mordechai's attitude to the less fortunate in society to be criticised. 
77). It is with this same attitude that Mordechai angrily demands his reward from the king and the chance of unexpected vengeance for himself and his people:

Wer hätte das gedacht... wer hätte jemals gedacht, daß ich vor dir stehen werd, großmächtiger König! - und als gerechten Lohn, der deinem und meinem Volk gleich nützlich ist, verlangen werd die Auslieferung der Frevler, die verbinden wollten deinen Sturz mit einem Blutbad, unerhört und grausam, unter meinem unschuldigen Volk.

$(\mathrm{I}, 80)^{8}$

It is only at this very late stage that Mordechai must learn the full truth about the authority he has served. Not only is the king, who concedes that Mordechai is in the right, unable to deliver what he demands, but in the future will himself turn to anti-Semitism to further his political agenda (I, 80-81). As in the scene with Benjamin, faced by this shocking truth Mordechai falls into despair. On this occasion it is Esther who must support the broken man. Echoing her brother's political position she too sees the only solution lying in a radical restructuring of society to make it just and fair:

Dieses Getrieben- und Geduldetsein, Unschuld- und Jammertragen, wird nie aufhören - nie! - solange unsre Welt aufgebaut wird durch namenlose Gier, Ausbeutung und Niedertracht! Zur Stunde aber, da geschleift wird dieser Zwinger, der von wenigen geschaffen wurde zum Gefängnis vieler zu dieser Stunde wird auch wie ein Rauch aufgehn all das, was ihr in Grübelei, Buchstabenweisheit, zu erkennen vermeint als unabänderliches Schicksal! - Doch glaub ich, daß die ersehnte Stunde noch fern ist...

Both uncle and niece turn their back on the corrupt power to which they have previously been bound. Mordechai's faith in law and order has been shown to be completely misplaced.

In many ways, Die Bürgschaft is similar to Esther, although there is no suggestion of Marxist sympathies in the later play. Both plays have overtly political content, and although quasi-historical in setting, Hochwälder emphasizes that the staging of both should be timeless and in the style of Commedia dell'arte (I, 8; IV, 84). Both plays are also populated by characters, who in the main, are concerned with protecting their own interests in troubled political times, regardless of who may get hurt in the process.

In this late work, completed in 1984, Hochwälder presents two naive characters, Heloris and Agathon, who put too much faith in the power and authority of their respective philosophies. Both desire the overthrow of the tyranny of

8 In notes probably prepared for a lecture given to the "Jüdischer Flüchtlingsverband in der Schweiz" on 30 April 1946, Hochwälder interpreted a central element of the original Esther legend as the desire of a persecuted minority to exact cruel victory over its persecutors and do to them as they had done to themselves [Fritz Hochwälder, "Purim als Gleichnis des jüdischen Galuth-Schicksals", typed notes, undated (April 1946?), Hochwälder Nachlaß, Wiener Stadt- und Landesbibliothek, Wien. 
Dionys, but see markedly different ways of achieving this: Heloris puts his faith in the power of the masses and strives for the violent overthrow of the dictator; while Agathon seeks to bring change about from within by persuading the tyrant to change his way of governing. Both ultimately fail because they over-estimate the power of their doctrines and allow themselves to be used by those more powerful than they .

The play is based, very loosely, on the fable by Hyginus, of which Hochwälder provides a synopsis in the introduction to the play (IV, 78-79), and Schiller's ballad "Die Bürgschaft", inspired by the same tale, which is also reproduced (IV, 80-83), thereby inviting comparison. However, Hochwälder's version of events is markedly different from that of his predecessors, and even the names of the protagonists have been changed, with Hyginus' hero, Moerus, and Schiller's Damon ${ }^{10}$, appearing only briefly as leaders of the triumphant "Partei der Gleichen", while their earlier roles are taken by Heloris.

More important than these influences are the writings of Plato, specifically his "Seventh Letter" ", which recounts Plato's failed attempts to influence the tyrant Dionysius II of Syracuse. Both in his efforts to change the government under Dionys and in the pronouncements he makes, Agathon, who significantly is Greek and not a native of Syracuse (IV, 120), can be seen as mirroring the great philosopher. The name Agathon is also given to a character in Plato's "Symposium"12, although Hochwälder might have deliberately chosen the name as a subtle allusion to the ancient dramatist credited with breaking from plot and characterisation based solely on myth ${ }^{13}$, since Hochwälder turns the original stories, upon which the play is based, upside down.

The play begins after the deed which starts Schiller's ballad, the failed assassination of Dionys, this time attempted by Heloris. However, Hochwälder

${ }^{9}$ As will be seen in Chapter 7, the political satire for which Hochwälder strives, with mixed success, in this play, can be closely linked to the dramatist's personal concerns about the nature of modern society, as expressed most clearly in "Kann die Freiheit überleben?".

10

It is interesting that Schiller in fact wrote two versions of his ballad, with Möros the protagonist of the earlier poem, Damon of the later. This along with a change in the title is the only variation between the two [Friedrich Schiller, "Die Bürgschaft", Gedichte in der Reihenfolge ihres Erscheinens 1776-1799, Hrsg. Julius Petersen und Friedrich Beißner, 1. Band von Schillers Werke. Nationalausgabe, (Weimar: Hermann Böhlaus Nachfolger, 1943), 421-425; Friedrich Schiller, "Damon und Pythias", Gedichte in der Reihenfolge ihres Erscheinens 1799-1805 - der geplanten Ausgabe letzter Hand (Prachtausgabe) - aus dem Nachlaß (TEXT), Hrsg. Norbert Oellers, 2. Band von Schillers Werke. Nationalausgabe, (Weimar: Hermann Böhlaus Nachfolger, 1983), 250-254]. The Encyclopedia Britannica would seem to confirm Schiller's alteration in its account of the legend, although it reverses the roles of Damon and Pythias, with Pythias condemned to death but allowed to visit his sister while Damon vouches for him ["Damon", Encyclopedia Britannica, 9th ed. (1903), vol. VI, 795].

11 Cf. Fritz Hochwälder, typed notes on Die Bürgschaft, undated, Hochwälder Nachlaß, Wiener Stadt- und Landesbibliothek, Wien.

12 Peter Levi, "Greek Drama", The Oxford History of the Classical World, ed. John Boardman, Jasper Griffin and Oswyn Murray, (Oxford: Oxford University Press, 1986), 157.

13 Martin Banham, ed., The Cambridge Guide to the Theatre, Rev, ed. (Cambridge: Cambridge University Press, 1992), 13. 
quickly departs from his forerunners by revealing that Heloris' wish to attend his sister's wedding before his execution is simply a ruse to further his political aspirations. These revolutionary intentions are hinted at by his confident promise to free his fellow inmates after his arrest (IV, 92) and are then confirmed when he speaks to Agathon. He reveals the plan to topple and kill Dionys in a violent coup, freeing the population and establishing a "Reich der Freiheit und Gerechtigkeit" (IV, 99). Against Agathon's protests he argues that: "Nur Gewalt hilft, wo Gewalt herrscht" (IV, 98). Convinced that his chosen path is right he adopts a position not dissimilar to Theresia Tallien's in Der öffentliche Ankläger, insisting that: "[...] alles, was zum Sturz der Tyrannis führt und unsere Machtübernahme fördert, ist nicht bloß erlaubt, sondern geboten: Das Ziel heiligt die Mittel". He ignores Agathon's warning: "Deine Mittel entheiligen das Ziel" (IV, 98).

However, as events unfold, Heloris' faith in himself, his cause and the people he aims to free proves to be sadly misplaced, as is quickly revealed by the selfserving behaviour of the majority of the characters in the play. Those in power prove able to anticipate events more capably than either Heloris or Agathon and their readiness to change sides, and confidence at being able to do so, suggests that little will change with the fall of the dictator. Of these, Charmides, the head of the secret police, is the only one to make a slight error of judgement. He has arranged for his police to welcome a triumphant Heloris with open arms when he arrives and is happy to be arrested by Dionys, since this will boost his credibility in the eyes of the "kommende Macht" (IV, 118119), but has failed to recognize that the power does not really lie with the would-be assassin of Dionys, but with his allies, Damon and Moerus. Even so it is not an irreversible error and he is confident of correcting this mistake when he learns the true state of affairs from Kratinos and Dexippos, who have, to use Charmides' terminology, backed the right horse (IV, 127). Dionys' shrewd political advisors, Kanes and Sacas, make no such mistake when deserted by their master; recognizing that Heloris is "ein unbedeutendes Würstchen" (IV, 123), they hurry to offer their services to the leaders of the "Partei der Gleichen", Damon and Moerus (IV, 124). The Oberhofmeister need not even go to such lengths, merely waiting for his new masters to arrive: "Die neuen Herrscher werden froh sein, hier einen vorzufinden, der mit dem Protokoll vertraut ist" (IV, 125), although taking the security measure of having Agathon arrested as he tries to return home (IV, 128).

Such cynical behaviour would also seem to be justified by historical experience, for as Kleonymus tells in his speech praising Dionys, the tyrant was elected by the people based on attacks he made on injustice and the wealthy before gaining power (IV, 113-114). Those hurrying to change allegiances would probably agree with Agathon's view: "Wenn Dionys fällt, dann kommt [...] nichts besseres nach" (IV, 122), for their behaviour is based on the assumption that, with some fancy footwork, things will stay as they are.

When the victorious revolutionaries arrive, such expectations are quickly confirmed. Heloris' Schillerian claim to fame: "Wer ist zu Dionys geschlichen, mit dem Dolch im Gewand [...]?" (IV, 129), counts for nothing, since 
such notions of heroism are meaningless in the cynical world of Realpolitik. His pleas for his friend Agathon fall on deaf ears: "Deine Privatangelegenheiten gehen uns nix an", and his protestations that worse criminals, like Manes and Sacas, now work for them are dismissed out of hand: "[...] die zwei sind professionelle Kreaturen, die drehn wir einfach um und nehmen sie in unsere Dienste" (IV, 129). The pragmatic approach to politics used earlier by Heloris against Agathon is now turned against him, and the position of the new leaders is reminiscent of Theresia Tallien's use of Fouquier's old informer for her own ends (I, 314), and her husband's readiness to confirm Grébeauval in his old position after Fouquier's fall $(I, 326)$. Heloris must reluctantly recognize what has happened: "Wenn eure Herrschaft so aussieht, dann haben wir jetzt statt eines Tyrannen deren zwei" (IV, 130).

Despite this setback, Heloris still has faith in the people, and he optimistically works out a plan to free a sceptical and resigned Agathon:

HELORIS: Wenn man dich morgen zur Richtstätte führt, brech ich mit meinen Gefolgsleuten aus dem Hinterhalt hervor und befrei dich im Handstreich. - Verzage nicht, mein Agathon - ich rufe auch die andern auf, ich appelliere an das gesunde Volksempfinden -

AGATHON: O weh, das gibt's ja gar nicht.

The older philosopher's doubts are proven well-founded when the rescue plan fails, due to the lack of support of the general population and the lack of resolve of Heloris' followers. Heloris is left to cry bitterly as he is arrested "Verblödetes Volk - kommts ihr denn ohne Tyrannen nicht aus?" (IV, 135). He has not only made the mistake of putting too much faith in the masses he hoped to free, he has also allowed this belief to draw him into an alliance with those who do not share his aims ${ }^{14}$.

Agathon does not put any faith in the masses as the vehicle of change, yet considers himself a revolutionary. His theories have much in common with the philosophy of Plato, or more specifically with the criticism of Plato made by Karl Popper ${ }^{15}$. They are initially conveyed not by Agathon himself, but rather by the sceptical first pupil, who recites Agathon's lecture "Von der wahren Revolution":

Der Übergang von der schlechtesten zur besten Ordnung darf dem Volk gar nicht zu Bewußtsein kommen. Aufgabe und Amt des Philosophen ist es, den Herrscher vom Ideal des gerechten Staates zu überzeugen. In der schwarzen Seele des Tyrannen muß sich der Gedanke des Guten entzünden. Dann steht eines Morgens, wie aus dem Boden gezaubert, der vollkommene Staat da.

(IV, 95-96)

\footnotetext{
14 The apparent incompatibility between the ideals of freedom and equality are discussed at length in "Kann die Freiheit überleben?" [see Chapter 7].

15 K. R. Popper, The Spell of Plato, 1945, Vol. I of The Open Society and its Enemies, (London: Routledge and Kegan Paul, 1977). Hochwälder quotes from this work in his essay "Kann die Freiheit überleben?" [see Chapter 7].
} 
This belief that good government can only come about through philosophical education echoes Plato's sentiments in his "Seventh Letter":

[...] the human race will not see better days until either the stock of those who rightly and genuinely follow philosophy acquire political authority, or else the class who have political control be led by some dispensation of providence to become real philosophers ${ }^{16}$.

Furthermore, Agathon's belief in the ability to change the system from within and the desirability thereof (IV, 112) is also in keeping with Plato's insistence, laid out in his "Republic"17, that in a just society each citizen shall not attempt to rise above their given position in society. Hence, Heloris' hope for a violent overthrow of the dictator is misguided in Agathon's eyes, for it is Dionys who, as a ruler, should rule, and Agathon, as a philosopher, who should provide guidance.

It is also in keeping with Plato's teachings ${ }^{18}$ that Agathon insists that "Unrecht leiden ist besser als Unrecht tun" (IV, 96; 131). For him the ends can never justify the means, and he can only reproach Heloris for the error of his ways: "Du bist weit abgeirrt von meiner Lehre" (IV, 98).

But if Agathon's philosophy is markedly different from Heloris', it is just as flawed. Where his former pupil naively puts his faith in the forces of popular revolution, Agathon places his in the power of philosophical rhetoric to change a cruel and tyrannical despot, and like Mordechai before him, reveals a belief in order above all else. That his plans will end badly is prophesied in the first scene in which he appears, when his mother watches him depart with the words: "Er kehrt nicht mehr zurück" (IV, 97). In addition to this, he also receives a timely warning from Heloris before they exchange places in prison: "Vergiß die strenge Regel nicht: Man halte sich fern von der Gesellschaft des Tyrannen - oder man sei ihm zu Willen" (IV, 99). But just as Heloris ignores Agathon's words of advice, so he too ignores this warning.

Agathon takes this opportunity to try to influence Dionys and reveals just how far removed his idea of revolution is from that of Heloris, whose actions he now denounces. It is, in keeping with Plato, the vision of a benevolent

16 Plato, "Letters", The Collected Dialogues of Plato Including the Letters, Trans. L. A. Post, ed. Edith Hamilton and Huntington Cairns, (Princeton: Princeton University Press, 1961), 1576. Such sentiments are also found elsewhere in Plato's work [Plato, "Republic", The Collected Dialogues of Plato Including the Letters, Trans. Paul Shorey, 712-713; Plato, "Laws", The Collected Dialogues of Plato Including the Letters, Trans. A. E. Taylor, 13011302], and it is stated in Laws "The best state [...] might arise out of an autocracy, provided, that is, there were a consummate legislator and an autocrat of disciplined character, and the transition would be particularly easy and rapid in that case [...]". Cf. Popper, The Spell of Plato, 44.

17 Plato, "Republic", 676.

18 "[...] we must [...] hold it a lesser evil to be victims of great wrongs and crimes than to be doers of them" [Plato, "Letters", 1583]. 
regal rule under the guidance of sound philosophy:

Der Jüngling, der heute früh den Dolch aus dem Gewand gezogen und dich auslöschen wollte, ist einer von jenen Dämonen, die mit Vorliebe bei Umwälzungen ans Tageslicht kommen und ein höllisches Spektakel vollführen - denn die größten Gefahren für den Staat liegen im Augenblick der Fessellosigkeit, die einen Umsturz begleiten! [...] Du, Dionys, kannst dem bösen Geschick noch entrinnen - zeige deinem Volk, daß du eine königliche Seele ${ }^{19}$ hast, und regiere fortan mit dem Philosophen! [...] ein einziger Mensch genügt, um das Gute zu verwirklichen, sofern er einen folgsamen Staat in die Hände bekommt. Ich will das bestehende Übel mit der Wurzel ausrotten, kein Stein darf auf dem andern bleiben, aber alles muß in Ruhe und Ordnung vor sich gehen - was nichts anderes heißt, als daß du, der großmächtige Machthaber, dich an die Spitze der Umsturzbewegung stellen mußt. - Revolution, ja, gewiß: aber von oben nach unten!

(IV, 112)

Like Mordechai, who rejects the activities of his nephew Benjamin, when confronted by the unfairness and corruption of government, Agathon hopes that reform can maintain stability and order.

Just how misguided such beliefs are, becomes clear when he is made Prime Minister by a desperate Dionys (IV, 120), who has earlier provided an apt metaphor for his own position: "Der Ertrinkende klammert sich an einen Strohhalm" (IV, 119). Agathon is full of confidence that he can instigate real change, but just how seriously Dionys takes his advice is shown by the fact that he only pays lip service to changing his habits, agreeing to drink milk rather than wine for breakfast in Agathon's presence (IV, 120), but dismissing the idea as soon as the philosopher has gone (IV, 121).

It is ironic then that, like Heloris who stumbles by putting too much faith in the general population, Agathon is also rejected by the masses. Expecting them to welcome the promise of reform from above, he finds the people, well aware of the precarious position of the tyrant, completely unreceptive to the idea (IV, 122). In the face of the advancing forces of Moerus and Damon, Agathon's reforms are doomed. He can only urge his master to flee with his daughter, so denying the mob he despises the chance to triumph over their tyrant: "[...] ich [will] verhindern, daß die Syrakusaner, die dir seit zwanzig Jahren zugejubelt haben, morgen gaffend und höhnend dein Kreuz umstehn. Denn der Pöbel hält es nur mit dem Ausgang und Erfolg einer Sache - und die Welt ist voll von Pöbel" (IV, 125).

In doing this Agathon effectively signs his own death warrant, for the new leaders, who prove to be much more sensitive to the base desires of the masses, and therefore, like Haman, adept at manipulating them, can use him as a ready sacrifice to provide sport for a vengeful crowd (IV, 130).

At the end of the play the dreams of both philosophers, as different as they are

19 Cf. Plato, "Republic", 803: "[...] there is no city more wretched than that in which a tyrant rules, and none more happy than that governed by a true king". 
in concept, have been soundly destroyed. Both have chosen to put their faith in powers of which they have little real understanding, and in doing so have deliberately ignored the warnings they gave to one another. Agathon rightly pointed out the corrupting nature of believing that the ends can justify the means, and Heloris found himself the unwitting accomplice of those seeking power for quite different reasons than his own. Agathon, on the other hand, ignored the warning that by working with tyranny to change it, he might become its tool. He has failed to recognize that the system he hoped to reform is fundamentally flawed, and while he saved the tyrant from his fate, he could not prevent new despots from taking his place.

In Die Bürgschaft both Heloris and Agathon allow themselves to be manipulated by greater forces in the misguided belief that, in doing so, things will eventually work out for the best. In Hochwälder's most renown play, Das heilige Experiment, the central character, faced with the moral dilemma of whether to subjugate himself to a higher power, does not even have this consolation, for his conscience implores him to resist authority. It is this conflict which is right at the heart of the drama, and which centres around the characters of the Provincial, Miura and Oros. Both the Jesuit and Spanish leaders choose, however reluctantly, to bow before their superiors and obey orders, while Oros alone offers defiance in what is ultimately a futile act of resistance. Yet despite the failure of Oros' stand, the play ultimately rejects the course of action taken by both the Provincial and Miura and insists on the moral duty to resist evil.

Unfortunately, in much of the secondary literature devoted to the play this central concern has been obscured by other perceived themes in the play, which upon closer analysis of the text, can be discounted. In Chapter 1 it was shown that it would be mistaken to draw the conclusion from the accusations of crass materialism levelled against the Jesuits and their Indian charges, that their spiritual position is somehow compromised. The same can also be applied to suggestions that the primary concern of the play is an examination of totalitarianism, or a pacifist rejection of violence.

To look for the theme of totalitarianism in a play written in 1942 and first performed in 1943 is perhaps understandable. Martin Esslin not only sees it as the central theme of the play but also as indicative of Hochwälder's way of thinking, for the dramatist has chosen the most benevolent and humane example of a totalitarian regime, the Jesuits in Paraguay, with which to examine the subject. It is, according to Esslin, never clear just where the dramatist stands in this debate, for all the characters, from their own points of view, can be seen to be correct ${ }^{20}$. This view that a concern with totalitarianism is a major theme of the play is also shared by C. D. Innes ${ }^{21}$ and Alan Best. The latter draws a parallel with Hochwälder's later play, Der Himbeerpflücker, and sees the play as demonstrating the dangers of reliance on external support with the appeal of the Jesuit order to the Indians as akin to the

\footnotetext{
20 Esslin, "Nachwort", 301.

21 Innes, 214-215.
} 
It is a chilling and unexpected comparison, but the retrospective light which Der Himbeerpflücker casts on Das Heilige Experiment [sic] (which was, after all, written during the Third Reich's most successful period) turns the Jesuit drama from a question of conscience into a study of the evils of individual reliance on external support ${ }^{22}$.

Yet, while the regime of the Jesuits may be authoritarian, it is far from totalitarian, and it is consistently portrayed in the play as something laudable. The play opens with Indians voluntarily asking Fernandez to be allowed to join (I, 85-86), and while the Jesuits do organize all aspects of community life, the Jesuit leader is quite capable of refuting to Miura's satisfaction the charge that the Indians are kept in slavery. He points out the necessity of the Jesuits taking control for the good of the Indians themselves:

Unsere Indios sind von harmloser, aber kindlicher Gemütsart. Wenn wir nicht das Saatgut austeilten - sie würden alles in wenigen Tagen auffressen. Wenn wir nicht das Fleisch austeilten - die Indios hätten in wenigen Wochen alle Ochsen geschlachtet. Unter der Notwendigkeit, allen alles zu sein, sind wir alles geworden [...] Aus unseren Händen empfängt das Volk alles, was zu seinem geistigen und leiblichen Wohl notwendig ist. Dadurch unterscheidet sich unsere absolute Herrschaft von sehr vielen andern weltlichen Regierungen.

$(\mathrm{I}, 101)$

It is the exemplary nature of the settlements which earns them enemies and ultimately leads to their downfall, a fact not lost on the Spanish settler Quesida who must contend with losing his slaves to the more appealing Jesuit communities:

Zwei Drittel des Grundbesitzes in Spanien gehört der Kirche und den Klöstern. Die Pfaffen sitzen im Fett, und das Volk ist mager. Unter dem Krummstab läßt es sich gut wohnen, aber im Reich, in dem die Sonne nicht untergeht, herrscht Elend und Verzweiflung...

(I, 107-108)

Such sentiments are later repeated by Miura [see below]. Compared with the Church policy elsewhere and the other Spanish domains the Jesuit state is a paragon of benevolence and fairness.

It would also be wrong to draw an overtly pacifist message from the play, as Eileen Murphy, Edward $\mathrm{M}^{\mathrm{C}}$ Donald and Donald Daviau, amongst others have attempted to $\mathrm{do}^{23}$. According to this interpretation the folly of violence is shown through the wounding of Fernandez, which demonstrates that Oros was

22 Best, 48 .

23 Murphy, 65-66; $\mathrm{M}^{\mathrm{C}}$ Donald, 92-93; Donald G. Daviau, Der innere Konflikt [...]", 910; Innes, 214-215; Banham, 449. 
wrong to fight the Spanish, and is confirmed when he asks for absolution and forgiveness. Cornelis' parting words to Miura at the end of the play, when he warns that violence will eventually destroy those who use it, are also used to reinforce the argument that this is indeed a pacifist play ${ }^{24}$.

This, however, overlooks the fact that the Jesuit state has a standing army, the existence of which is stoutly defended: it has, in the past, not only defended the community from bandits, but also fought for the King of Spain (I, 112113). Fernandez, the apparent advocate of peace, is more than ready to make use of the militia before speaking with Querini.

Likewise, the Dutch trader's remarks to Miura at the end of the play should be seen as a criticism of the way Spain has employed force to conquer all with the sword, not as a rejection of self-defence $(I, 137)$. Indeed, he applauds Fernandez's fighting talk at the start of Act III (I, 120).

It is Querini alone who openly rejects the use of violence: "ich werde es nicht zulassen, daß wir selbst von der Gewalt Gebrauch machen!" (I, 121). Since he later advocates the Church's position as being on the side of the powerful, not noted for their pacifist sentiments, he seems an unlikely bearer of any message of peace the play might have. The argument that Fernandez's fatal wounding is proof of the futility of violence is scarcely logical, since had he stuck to his original resolve to defend the state he would not have been caught in the crossfire. One could equally well argue that efforts to keep the peace are futile. Some confusion may have arisen from the appalling English translation by Eva le Gallienne ${ }^{25}$, which is taken from the French translation of the original. In this version of the play, in which the original five acts are reduced to two, pacifist sentiments are uttered by Fernandez, words which unfortunately have no correlation to the German text. On his deathbed he says: "You and I were wrong, Oros. Violence can never conquer violence - bloodshed solves nothing"26.

But, although it is without any pacifist intent, Hochwälder has quite consciously introduced violence into the play which has no historical basis. In fact much of the dramatic tension and action is invention. Historically the Jesuits meekly accepted the edict issued in 1767 which banished them from Paraguay ${ }^{27}$, and, significantly, from all Spanish territories ${ }^{28}$.

To find a historical precedence for the violent struggle in the play it is necessary to go back a further two decades to 1750 , when Guarani Indians did fight

24 Murphy, 65-66.

25 Fritz Hochwälder, The Strong are Lonely. A Play in Two Acts, trans. Eva le Gallienne from the French version by J. Mercure and R. Thieberger, Plays of the Year, vol. 14 (London: Elek Books, 1956), 13-120.

26 The Strong are Lonely, 118. Also note the Provincial's advice to Oros about defending themselves: "How, Father Oros, except by the shield of faith and the sword of the spirit?" (30).

27

R.B. Cunninghame Graham, A Vanished Arcadia. Being Some Account of the Jesuits in Paraguay 1607-1767, (London: Century, 1988), 235 [first published 1901]; J. C. H. Aveling, The Jesuits (London: Blond and Briggs, 1981), 281.

${ }^{28}$ David Mitchell, The Jesuits. A History (London: Macdonald, 1980), 177. 
back after several Jesuit communities were ordered to be vacated and given over to the Portuguese in $1750^{29}$. This has prompted one historian to state: "Hochwälder seizes on two disparate crises, confuses his story by telescoping them, and sacrifices dramatic impact by departing from the facts" 30 . On the contrary, it is by altering the historical events that the author creates the dramatic conflict at the heart of the play ${ }^{31}$. By suggesting that the order can still be saved in Europe, Hochwälder makes the command to leave Paraguay at least partly understandable, while Oros' defiance offers a tangible alternative to following orders from above. By departing from the historical basis of the play the question of resistance or compliance becomes central, and the position of both Alfonso Fernandez and Oros can arouse the audience's sympathy.

In ascertaining just what Hochwälder intended by the introduction of violence to the story, and, in doing so, further discounting any pacifist intent, it is profitable to look at the play's unpublished forerunner, "Die Jesuiten in Paraguay". As has already been mentioned, this version lacks the subtlety of the final product and the central focus is firmly on the Spaniards, notably Miura, who rejects his orders once he sees how unjust they are, and his far more ruthless subordinate, Villano, who carries through the destruction of the Jesuits' state. Nevertheless, the figure of Oros is largely unchanged, and, keen to defend the Jesuits' work against the Spanish "Pest", he is rebuked early on by his superior with the words "auf diesem Schlachtfeld kann der Sieg nicht unser sein!" (DJIP, 50). In this version, the figure of the Provincial does not play such an important role, and it is Oros who is carried on stage wounded after resistance fails. Significantly the dying Oros, as in the final version, asks his superior for forgiveness, only to be told in no uncertain terms:

Du hast gut gehandelt, mein Sohn! Du hast das Schwert erhoben wider die Feinde des Rechtes und der Menschlichkeit! Als dein Beichtvater und dein Freund sage ich dir: du hast gut gehandelt! [...] Es ist ein grosses Verdienst, Gott um Gottes willen zu verlassen! Gross und wahrhaftig edel war dein Vergehen - vor Gottes Richterstuhl wirst du belobt werden für

29

Mitchell, 194-195. This was under the terms of the Treaty of Madrid, which was intended to settle South American territorial disputes between Spain and Portugal. It is interesting to note that the 1986 film, The Mission [dir. Roland Joffé, Screenplay Robert Bolt, with Jeremy Irons and Robert de Niro, Enigma Productions, 1986], which is very loosely based on Das heilige Experiment, is set in 1750 and the destruction of the reductions is the result of Spanish and Portuguese diplomacy, aided and abetted by the Church. Hochwälder is not acknowledged in the credits, according to its director, at his own request: "Wir hatten Hochwälder das Drehbuch als erstem zugeschickt, und es hat ihm sehr gefallen. Weil er aber erkannte, daß Robert Bolt eine ganz eigenständige Story gebaut hatte, bat Hochwälder selbst, seinen Namen wegzulassen" [Ludwig Heinrich, "Mischwald statt Hochwälder", Oberösterreichische Nachrichten [Linz], 22. Dez. 1986, 9. [Also as: "Das heilige Experiment als Vorlage für den Film Mission". In: Tiroler Tageszeitung (Beilage), 27/28. Dez. 1986].

30 Philip Caraman, The Lost Paradise. An Account of the Jesuits in Paraguay 1607-1768, (London Sidgwich and Jackson, 1975), 14.

31 Hochwälder indicates that it is far from his intention to render an accurate historical accounts in his plays with reference to "die Einkleidung meiner Themen in historische Kostüme" [Im Wechsel der Zeit, 94]. 
In this earlier version, there can be no doubt about the assertion of the duty to fight for what is right. In Das heilige Experiment, however, nothing is quite so clear cut, and the blurring of the lines between what is morally acceptable and what is wrong contributes to making it such a powerful drama. The central focus of the play is on the protagonist, Provincial Alfonso Fernandez, and it is to this character, and to a lesser extent Miura and Oros, that attention must be paid if the play is to be understood. The Jesuit leader must grapple with the dilemma of how to respond not just to the secular threat to their work in Paraguay, but also to the ecclesiastical attack, which brings his whole way of life and commitment to the order into question.

During the first act, the Provincial's position changes from one of supreme confidence to a recognition of the threat the reductions are facing. The danger is recognized early on by Cornelis, who, although a friend of the Jesuits, serves as a neutral observer on proceedings since he is neither a Catholic nor a Spaniard. As early as the first act, he sees the writing on the wall for the reductions, and prophesies: "Ihr seid verloren". But Fernandez is supremely optimistic, countering: "Aber wir sind unaufhaltsam" (I, 93). He has complete faith in both the Spanish throne and the Church $(I, 89)$ and expects a fair hearing when Miura arrives. Yet the seriousness of the situation becomes apparent when Miura assumes power for the course of the investigation at the end of Act $\mathrm{I}$. The position of Fernandez is symbolically underscored by the last stage instruction of the act: "Vor der Landkarte stehend, erhebt er langsam die Hände, als schütze er den Staat" (I, 95).

Nevertheless, as long as a pretence of legal justice is placed on proceedings in Act $\mathrm{II}^{32}$, the Jesuits are easily able to refute the allegations made against them [see Chapter 1], and can confirm their loyalty to the king: "solange der König keine Sünde von uns verlangt" (I, 99), a condition of obedience that will shortly take on great significance for both Fernandez and Oros.

The disguised legate Querini takes little part in proceedings, indicating that the vindication of the Jesuits is of no concern to him. He poses one question to Cornelis, who has given praising testimony to the exploits of the Jesuits, establishing that the Dutchman is a Calvinist, and, therefore, a heretic (I, 111 , which, in the eyes of the Catholic Church, must surely make his sup-

32 Act II actually opens with two of Miura's subordinates. Their conversation, concerning evidence, or rather the lack of it, against the Jesuits quickly makes clear that the state is doomed: "Der Fettfleck soll verschwinden von der Landkarte" (I, 96). Nevertheless, a hearing must take place, if only to try and find some justification after their fate has already been decided, for the Spaniards "müssen vor der ganzen Welt im Recht stehen" (I, 97). It is interesting that the image of "Fettfleck" used here to denote the Jesuit state is again used in the much later play Donnerstag in which a genuine stain proves impossible to remove from the protagonist's suit. In both plays the "Fettfleck" can be seen as a symbol for the conscience, that very characteristic which defines humanity: in Das heilige Experiment for that of the world, pricked by the Jesuit example, in Donnerstag for that of the hero, who is tempted to sacrifice it for a trouble-free life. 
port suspicious.

The hearing successfully negotiated by the Jesuits, and with no clear evidence to justify the dissolution of the Jesuit missions in Paraguay, Miura must reveal the full injustice of the edict demanding their destruction. In a scene reminiscent of the closing moments of Esther, where the king concedes that Mordechai is right, but nevertheless condemned to persecution, Miura also concedes that the Jesuits have right on their side, but have created something which is politically unacceptable and a dangerous example in an unjust world:

[...] Ein Reich der Liebe und Gerechtigkeit. Ihr sät und erntet ohne Habgier - die Indios singen euer Loblied - und laufen unsern Grundbesitzern davon! Eure Produkte gehen in die Welt hinaus - unsere Händler verarmen. Bei euch herrscht Frieden und Wohlstand - im spanischen Mutterland Elend und Unzufriedenheit. Dieses Land, das wir mit unserm Blut erobert haben - ihr macht es groß: gegen uns! Ein kleines Volk seid ihr in eurem Staat - und wir, die Mächtigen, müssen vor eurem Beispiel zittern! [...] Narren wären wir, wenn wir euch nicht verjagten, solange es noch Zeit ist! Ihr müßt weg! Im Namen des Weltreichs, das euch gestattete, hier euer Kulturwerk zu versuchen: weg mit euch! Schluß mit diesem Experiment, das uns gefährlich wird! Schluß!

Miura's absolute loyalty to the crown means he is willing to carry out orders he knows to be unjust. But for the Provincial there is, as yet, no conflict of interest, for his loyalty to the crown stops as soon as it requires him to sin. The decision to resist the Spaniards is effectively made for Fernandez by the entrance of Oros with the news that the Indians, alarmed at rumours circulating the college, have arrested the Spanish (I, 118).

Fernandez is convinced that the king has been deceived by those around him. Act III begins with the Provincial making a call for resistance in a passionate speech, the significance of which seems to have been overlooked in the secondary literature on the play. It is an impassioned statement on the limitations of office and of the duty to offer resistance against injustice:

Wer aber sein Amt überschreitet und sich Gott entgegenstellt, soll seines Ehrentitels entkleidet werden, damit er nicht unter der Maske seines Amtes unermeßlichen Schaden stifte. In solchem Fall Widerstand zu leisten ist

33 Richard Thieberger has argued that the central theme of the play is the conflict between might and right. In light of this, and while acknowledging that half the play is still to come, he sees this scene, II.8, as the key to the play [Richard Thieberger, "Macht und Recht in den Dramen Fritz Hochwälders", Gedanken über Dichter und Dichtungen. Essays aus fünf Jahrzehnten. (Les textes et les auteurs. Cinquante années de réflexions sur la litterature), Von Thieberger, Hrsg. Alain Faure, Yvon Flesch und Armand Nivelle, (Bern: Peter Lang, 1982), 276]. However, with regard to the dramatic action still to come, it is hard not to agree with U. Henry Gerlach that it is not the truism that power can be used to do evil that is important in the play, a fact patently obvious in 1942, but rather how power is allowed to be so used [Gerlach, "Unterdrücktes Gewissen als Zentralmotiv in Fritz Hochwälders Heiligem Experiment", 360-361]. 
Forderung der Religion. Die Verleumdung, die Lüge, die Niedertracht erobern mit dem Schwert Völker, die die Lüge, die Verleumdung, die Niedertracht hassen. - Ausgespien wären wir aus Gottes Mund, wenn wir zögerten, unseren freien Willen zum Widerstand anzuspornen!

This, in essence, is the underlying message of the play: the individual should not escape personal responsibility for the actions he commits, regardless of the office he holds.

Both Cornelis and Querini are present to witness this passionate declamation, and once again the question of heresy is raised by the trader's enthusiastic response. He shows that ideological persuasions have little to do with recognising what is right or wrong, humorously observing: "In Ordnung! Schade nur, daß Ihr - kein Calvinist seid!" (I, 120).

Yet, moments later Fernandez crumbles when his religious superior, Querini, insists that he carries out the Spaniards demands; the Church also wishes an end to the Paraguayan experiment, in order to save the Jesuits in Europe. He attacks the reductions on several fronts: firstly by arguing: "Diese Welt aber ist ungeeignet zur Verwirklichung von Gottes Reich" (I, 122); then by claiming that the Church must side with those in power, for "Im Herzen der Grausamen und Mächtigen müssen wir die christlichen Tugenden erwecken" (I, 122), and that by entering the world of politics, the Jesuits have alienated powerful supporters in Europe; and finally by denouncing the experiment as heretical, indistinguishable from Calvin's Geneva. The Jesuits have attracted the Indians by material not spiritual means (I, 123). Their work has earned the disapproval of the Pope and should perhaps be investigated by the Inquisition. Fernandez, however, remains unmoved. He defends his Indians and believes that the Church must side with the downtrodden: "Wir können nie und nimmer die Seelen retten, wenn wir die Völker schutzlos der Unterdrückung überlassen. Eindeutig müssen wir unseren Platz beziehen an der Seite der Mühseligen und Beladenen" ( $\mathrm{I}, 123)$. He is even willing to face the Inquisition for what he believes is right (I, 124). He begs Querini to reconsider and investigate their work for himself.

Faced by such obstinacy, Querini resorts to calling on his authority as the Provincial's superior, and insisting he follow his oath of absolute obedience. In doing so he reveals the full inhumanity of his command; "Es geht um den Bestand des Ordens - und Ihr sprecht von hundertfünfzigtausend Menschen" (I, 124).

The Church and King in which Fernandez had believed so strongly in Act I have now deserted him. Yet confronted with a direct command from his superior he chooses to obey rather than listen to his conscience. In this he finds himself in the same position as Miura, serving the institution in which he believes, despite knowing what he is doing is wrong. Not that such a decision is easy: he visibly struggles to carry out his orders, particularly in the face of appeals from both Jesuits and Indians, and remains a very sympathetic character.

His world now collapsing he tries to justify his actions retrospectively, in 
much the same way that the Spanish hoped to find evidence of the Jesuits' guilt after already having passed sentence on them. Thus, his conversation with Oros (I, 125-126) seems to justify his compliance with Querini's orders, for Oros, who still believes they will resist, affirms his absolute obedience to Fernandez, and his faith in his leader's judgement.

Then in conversation with the newly converted Indian chiefs (I, 132-133), Fernandez seems to confirm the accusations of materialism made against them [see Chapter 1]. This provides further grounds for following orders. It is, however, significant that both conversations take place after Fernandez has taken the fateful decision to obey his superior, and are not the reasons why he followed his orders.

Some critics have seen the Provincial as powerless to do anything but obey orders. Edward $\mathrm{M}^{\mathrm{c}}$ Donald has argued that to do otherwise would have led to a massacre ${ }^{34}$, while Otto Rommel interprets the play as a modern tragedy, in which the protagonist battles in vain against anonymous and semi-anonymous forces $^{35}$, a view quoted approvingly by Wilhelm Bortenschlager ${ }^{36}$. However, it is made quite clear in Act III that the Jesuits are more than capable of offering sizeable resistance to the Spanish forces. Miura is certainly well aware of their strength and is incredulous when the Provincial hands over power: "Aber - wir sind doch nun in eurer Macht. Die Kommissionen - ihr erledigt sie mit einem einzigen Regiment. Ehe die Strafexpedition aus Spanien eintrifft habt ihr für einen jahrelangen Krieg gerüstet" (I, 127). Clearly, it is not the fear of defeat or a bloodbath that stops Fernandez resisting, he was after all prepared to fight initially, but the orders he has received from his superiors.

It is left to Oros to offer the only genuine resistance. Ironically, the former soldier, a man drilled in obedience, is the one to reject following orders. He argues, as Fernandez had done earlier, that one's oath of obedience does not extend to being led into sin (I, 131). Further echoing Fernandez, he insists that the Church's place is with the oppressed: "Es wird Euch nicht gelingen - dieses Werk [...] ungeschehen zu machen. Und solange ich Kraft habe zu atmen, zu rufen, zu kämpfen - werde ich an der Seite der Armen, der Schwachen und Unterdrückten stehen!" (I, 132). Fernandez feels he has no choice but to expel Oros from the order, and moments later is mortally wounded while trying to stop the Oros-led revolt.

The final act opens with Miura enforcing brutal punishment in response to the Indians' rebellion. One Indian from each reduction is to be executed "Zur Abschreckung" $(I, 137)$. Nonetheless, Miura is not the same person who arrived only hours earlier, convinced of his mission, and as he signs the death warrants there is more than a hint of a desperate attempt to convince himself of his actions: "Wir können wohl nicht anders. ... Auch wenn wir wollten ... Denn die Dinge selbst - gehorchen nicht immer unsern Gefühlen und Absich-

\footnotetext{
$34 \mathrm{M}^{\mathrm{C}}$ Donald, 92-93.

35 Otto Rommel, "Nachwort", Das heilige Experiment. Schauspiel in fünf Aufzügen, von Fritz Hochwälder, (Stuttgart: Reclam, 1964), 77.

${ }^{36}$ Bortenschlager, Der Dramatiker Fritz Hochwälder, 62.
} 
ten ..." (I, 137).

Perhaps the key scene to understanding the play as a whole is Act V, scene 3, in which the often misinterpreted dying words of Fernandez are uttered:

Bereue, und es wird dir vergeben ... Ich bin Provinzial, ich vergebe dir deine Schuld, damit auch mir vergeben werde, denn ketzerischer Überzeugung bin ich geblieben - und ich bereue nicht! -- Wir sollten uns an die Seite der Gewalt stellen? - Nie! - Wir sollten verzichten auf Gottes Reich in dieser Welt? - Nie! - Oh - ich höre die Stimme des Widersachers in meiner Brust, sie spricht: Nie! Nie! - Zu meinen Untergebenen aber sagte ich: Ich befehle! - Hört ihr! - Gehorcht! - und ich selbst gehorchte ... der Stimme des Widersachers in meinem Herzen ... Erst im Zorn verfluchte ich diesen Staat, als die leibliche Wunde mich schmerzte, vernichtete ich mit meinen Händen dieses Werk ... und so verlasse ich diese Welt, in der noch immer allüberall Unterdrückung herrscht ... und so ist alles vergeblich gewesen ....

(I, 138-139)

These words are certainly not as direct as those of Pater Sepp in "Die Jesuiten in Paraguay", and this may account for the varying interpretations. They have been seen as showing: that his dilemma remains unresolved in his own mind $^{37}$; that he recognises that he was wrong ${ }^{38}$; and even that he was right in following his orders ${ }^{39}$. For Daviau, who propounds the latter view, the Provincial is torn between loyalty to his Indians and loyalty to his order, the latter in the end taking precedence $e^{40}$. He sees in the dying Provincial not a broken man, or even a figure torn between conscience and duty, but a man at peace with himself, convinced he was right ${ }^{41}$. Miura has told him that the Jesuits were in the right, a fact underlined by the repentance of his opponent after the Provincial's death ${ }^{42}$. He dies full of confidence about the future, convinced his work will provide an example to others. Daviau also notes the enthusiastic response the play received in post-war Europe, attributing this to the relevance of its themes, stating: "What makes the play so moving is that most of the principals are basically good men acting under higher orders with which they do not necessarily agree" 43 .

But it is impossible to defend such positions when the final scenes are closely examined. Oros, facing execution and now regretting the events that led to

37 Murphy, 66; Schmitt,'The Theme of Responsibility [...]" 57.

38

Holdman, 182-183; Gerlach, "Unterdrücktes Gewissen als Zentralmotiv in Fritz Hochwälders Heiligem Experiment", 361, 364.

39 Daviau, "Fritz Hochwälder", 245, also "Der innere Konflikt [...]", 909; "Fritz Hochwälder's Range of Theme and Form", 35.

40 Daviau, "Fritz Hochwälder", 244.

41 Daviau, "Fritz Hochwälder's Range of Theme and Form", 35; "Fritz Hochwälder", 245; "Der innere Konflikt [...]", 909.

42 Daviau, "Der innere Konflikt [...]", 909; "Fritz Hochwälder", 244.

43 Daviau, "Fritz Hochwälder", 244. 
Fernandez being shot, which would seem to confirm he was wrong, asks for absolution. But from the words of Fernandez, it is clear that he now acknowledges the inner voice of his conscience. He rejects the Querini doctrine as wrong, something he has really known all along. Any doubts he might have had about his work in Act IV are now unequivocally gone, and heresy ${ }^{44}$ or not, the Provincial rejects standing on the side of power, and refuses to accept that their work has been wrong.

Considering the destruction of the reductions is now a foregone conclusion, and taking into account his personal role in this, one might expect the Provincial's dying moments to be filled with despair. Yet it is not with resignation that he dies. He takes heart from a picture of Franz Xaver, the saint who died alone and seemingly forgotten, yet whose inspiration has remained. This gives Fernandez the hope that his work will go on (I, 139). The image of the isolated Xaver is a fitting one, for the play shows us that in the end the individual has no one but himself and his own conscience upon which he can rely. The final scene provides faint hope that his dying belief may be justified. Miura, after witnessing the destruction of the Jesuit state, now finds his conscience, his inner voice, troubling him. In this final act the authority he serves has come under close scrutiny. The brutal punishment he endorses, the parting words of Cornelis: "Ist Euch die Hand lahm geworden vom vielen Tod" $(137)^{45}$, and the doubts in his own mind, all serve to highlight the injustice of the regime he represents. He finally can face it no more and repents to FerBnandez:

Und doch - ist in meinem Herzen ... etwas ... das spricht: [...] "Was hülfe es, wenn ich die ganze Welt gewönne, und nähme doch Schaden an meiner Seele ..." [...] auch diese Stimme ist in meinem Herzen, Alfonso Fernandez ... [...] Ich bekenne ... ich bekenne...

The entire emphasis of this final act is on individual conscience ${ }^{46}$, centred around the dying words of Fernandez and the repentance of Miura. In the final words of Fernandez and Miura the validity of the inner voice they both refer to $^{47}$ is recognised. The individual must rely on his own conscience and can-

44 That heresy is not a significant issue in the play is clear from the very sympathetic portrayal of Cornelis.

45 A phrase echoed by Fernandez when describing Xaver; "Seine rechte Hand ist lahm geworden, so viele hat er getauft" (139).

46 It is worth noting that Hochwälder altered the last act of the play for the 1964 Burgtheater production, and it is this version that is given in both the Reclam and Styria editions of the play. While minor alterations were made to the scenes the most significant change was the order in which they appeared. In the original the act began with the Provincial's dying speech to Oros, before proceeding to the punishment of the rebels, the deportation of the Jesuits, Cornelis' departure and finally Miura's confession. The overall effect is to make the act much more compact, four scenes instead of the original six, and heightens the impact of Miura's repentance, by having it immediately follow the Provincial's dying words.

47 An image which evokes Schimke's later message of hope in Die Herberge that justice lies "In unserer Brust" (II, 137). 
not put his faith in any external power. The tragedy of the play lies in the fact that both men have chosen to place their belief in the powers they serve, rather than to take heed of their own consciences, discovering the error of their ways when it is too late.

Of all the plays in which characters choose to follow the dictates of a higher authority rather than their consciences, Das heilige Experiment has the most tragic results, not least because the men responsible, Fernandez and Miura, are seen to be fundamentally good. They learn, as do the characters in Donadieu, Die Herberge, Esther, and Die Bürgschaft, that there can be no escaping personal responsibility through subjugation to authority or a higher order. Characters who attempt to justify their behaviour in terms of faith, philosophy, or patriotism rather than by confronting the moral validity of their actions themselves, inevitably fail to achieve their desired goals.

But this failure of various authorities to provide the leadership sought or to control individual behaviour for the good is also a result of human weakness, since such organisations can only be as good as their administrators: corrupt kings, brutal soldiers, judges that do not believe in justice, and religious figures concerned with power rather than morality all undermine any chance that the authority they have vested in them may be used for the good.

Characters in Hochwälder's dramas repeatedly demonstrate that there is no escaping individual responsibility; nothing can absolve the individual of the burden of conscience. External controls prove inadequate for guaranteeing justice, and often provide the justification for blatant injustice. When confronted by ethical dilemmas the individual is fundamentally isolated, and must rely on himself or herself when deciding how to act. 